NBER WORKING PAPER SERIES

\title{
ONE RING TO RULE THEM ALL? GLOBALIZATION OF KNOWLEDGE AND KNOWLEDGE CREATION
}

\author{
Richard B. Freeman \\ Working Paper 19301 \\ http://www.nber.org/papers/w19301 \\ NATIONAL BUREAU OF ECONOMIC RESEARCH \\ 1050 Massachusetts Avenue \\ Cambridge, MA 02138 \\ August 2013
}

Forthcoming: Nordic Economic Policy Review: Globalization, Labour Market Institutions and Wage Structure, 6th Issue, 2013. The views expressed herein are those of the author and do not necessarily reflect the views of the National Bureau of Economic Research.

NBER working papers are circulated for discussion and comment purposes. They have not been peerreviewed or been subject to the review by the NBER Board of Directors that accompanies official NBER publications.

(C) 2013 by Richard B. Freeman. All rights reserved. Short sections of text, not to exceed two paragraphs, may be quoted without explicit permission provided that full credit, including $\odot$ notice, is given to the source. 
One Ring to Rule Them All? Globalization of Knowledge and Knowledge Creation

Richard B. Freeman

NBER Working Paper No. 19301

August 2013

JEL No. F11,F16,F22,F66,J24,J44,J81

\begin{abstract}
$\underline{\text { ABSTRACT }}$
This paper directs attention at the globalization of knowledge and knowledge creation as the fundamental global driver of economic outcomes in today's information economy. It documents the globalization of knowledge and spread of scientific research from advanced to developing countries and argues that these developments undermine trade models in which advanced countries invariably have comparative advantage in high tech goods and services; determine the immigration of skilled workers; boosts labor standards; and influences incomes and inequality within and across countries. To the extent that knowledge is the key component in productivity and growth, its spread and creation is the one ring of globalization that rules the more widely studied patterns of trade, capital flows and immigration, per my title.
\end{abstract}

\title{
Richard B. Freeman
}

NBER

1050 Massachusetts Avenue

Cambridge, MA 02138

and NBER

freeman@nber.org 
From the 1980s to the 2010s, globalization was a major driver of economic change worldwide. Analysts and policy-makers debated the rules for international economic transactions and their effects on workers and living standards, focusing on what I will call the "three rings of globalization under the economic sky": trade of goods and services, international flows of capital, and immigration. The fall of the Soviet Empire, China's move to a market-based economy, and the adoption of export-oriented growth strategies by India, Latin America, and other developing countries altered all three flows in major ways. World trade increased relative to GDP as global treaties reduced tariffs and related barriers and as developing countries led by China turned into major exporters along global supply chains. International capital flows increased at unprecedented rates. High skilled immigrants moved across country lines in increasing frequency and low skilled often undocumented workers and refugees kept the number of immigrants increasing as well. Far from being substitutes, in this period trade and flows of factors of production were, if anything, complements. ${ }^{1}$

Advocates of globalization argued that free trade would improve the economic lives of workers in all countries. Some believed that capital flows would also improve economic well-being, though even ardent free traders expressed concerns over the instability of international capital flows ${ }^{2}$. Critics of globalization argued that trade without international labor standards would lower the well-being of less skilled workers in advanced countries and create a race to the bottom in labor standards in developing countries. In ensuing years some outcomes diverged from what advocates promised and others diverged from what critics feared, but viewed as a project to bring the bulk of humanity into a single market-oriented economic system, globalization succeeded famously.

Without downplaying the role of trade, capital, and immigration in altering employment, wages, and working conditions around the world, in this paper I direct attention at an aspect of globalization that has a potentially more important impact on economic life in today's information economy: the globalization of knowledge and knowledge creation.

\footnotetext{
${ }^{1}$ For analyses of goods and factor flows as complements see Markussen (1983) and Wong(1986).

${ }^{2}$ Bhagwati (1998) was particularly outspoken against international capital mobility.
} 
My analysis unfolds in two sections.

Section one presents evidence that the globalization of higher education in the form of rapidly increasing university enrollments worldwide and even greater proportionate increases in international students has altered the locus of the key determinant of modern economic growth - the knowledge base for production, and has globalized the production of scientific research in ways that were unimaginable a short while ago.

Section two argues that the globalization of knowledge has wide-ranging effects on economic activity and labor worldwide. By moving developing countries closer to the production possibility frontier, it undermines the "North-South" model of trade that positions the comparative advantage of advanced countries in their dominance of high value added goods and services at the frontier of technology; affects the immigration of skilled workers; boosts pressures for higher labor standards; and influences the level of incomes and inequality within countries and across the globe. To the extent that knowledge is the key component in productivity and growth, its spread and creation is the one ring that rules them all of my title.

\section{Globalization of Knowledge and Knowledge Creation}

The rapidity with which developing countries expanded their higher education systems and graduated huge numbers of workers in science, engineering and technology, and moved toward the frontier of science and innovation is one of the great surprises of the era of globalization.

Exhibit 1 records the number of students enrolled in tertiary education (college or university, including two year colleges) in developing and advanced countries from 1970 to 2010, based on data from UNESCO. In 1970 although developing countries constituted about $80 \%$ of the world population, they had 54\% of university enrollments. As a result of the destruction that the Maoist cultural revolution wreaked on China's educational system, China had less than 300,000 college and university students. The other population giant India had 2.5 million students. Among advanced countries, the US was the pioneer in mass higher education. Although the US had about $6 \%$ of the world population, in 
1970 twenty-nine percent of college or university students were American. Many other advanced countries had begun expanding their higher education systems in the 1960s but did not reach the USlevel of mass higher education until the 1990s.

By 2010, the division of university students and graduates around the world had changed markedly. Developing countries had over three-quarters of university students. China enrolled 30 million students and graduated 5-6 million persons with university degrees, many in science and engineering. India was slower in expanding its higher educational system but still enrolled 21 million persons in 2010 and more than doubled the number of Indian Institutes for Technology from 1970 to 2010s. ${ }^{3}$ Other developing countries also invested heavily in university education, building new universities and expanding older ones. For example, the International Association of Universities (IAU) listed 82 institutions of higher education for Bangladesh in 2012 compared to the dozen or so that existed in the 1970s. - This growth came about through the entry of many private universities as well as public institutions. Similarly the IAU reports that Chile had 90 universidads and Instituto Profesionals in 2012, which compares to 16 in the 1970 s. ${ }^{4}$ By the early 2000s many advanced countries attained similar or higher rates of enrollment of persons of the relevant age in college and university than the US. Still, the share of tertiary students in advanced countries beyond the US began trending down as the advanced country share of world population fell and as developing countries increased enrollments rapidly. The US share of enrollments was $11 \%$ in 2010 and shrinking.

At the highest level of academic training, there was a similar pattern of globalization as many countries invested in doctorate programs. China increased the number of graduating $\mathrm{PhDs}$ in the natural sciences and engineering to exceed the number in the US in 2007 (though it fell short of the total science and engineering degrees due to much larger numbers of social science PhDs in the US). Among the European countries, Sweden graduated more S\&E PhDs per person in the relevant age

\footnotetext{
${ }^{3}$ The six that existed in 1970 grew to 16 by 2012. See http://en.wikipedia.org/wiki/Indian_Institutes_of_Technology ${ }^{4}$ http://www.iau-aiu.net/sites/all/files/b_nw.pdf\#Bangladesh and Chile. The figures for the 1980s are from Freeman, 2010a: Richard B. Freeman," What Does Global Expansion of Higher Education Mean for the US?" in Charles Clotfelter (ed) American Universities in a Global Market University of Chicago downloadable at http://papers.nber.org/books/clot08-1
} 
group than the US while the EU overall graduated nearly twice as many natural sciences and engineering PhDs as did the US. ${ }^{5}$ Indeed, the number of American citizens getting PhDs did not change much in the 1990s and 2000s. What maintained US doctorate production were international students, who earned about one third of the PhDs in science and engineering in 2009 and accounted for over half of engineering, computer science, and physics doctoral degrees.

To be sure, the quality of higher education in developing countries that were rapidly building up their universities and increasing enrollments fell below the quality of higher education in advanced countries. In Shanghai's Jiao Tong University ranking of universities 190 of the top 200 universities were Western (with five of the ten non-Western in the top 200 in China, including 2 in Hong Kong). And while the US share of degrees fell, US universities maintained their position as global leaders in higher education, holding $40 \%$ of the top hundred and $37 \%$ of the second hundred in the Shanghai ranking. ${ }^{6}$ The London Times Higher Education ranking of universities shows a similar pattern with 93 advanced country universities in its top 100, and 43 in the US. ${ }^{7}$

More relevant for the labor market, McKinsey's 2006 study of the supply of graduates around the world (published as Farrell, 2006)

found that the recruiters of Western firms viewed only $13 \%$ of university graduates from 28 low wage countries, including China, India, and Brazil, as "suitable to work in a multinational company". The recruiters based their assessment on English language skills, cultural fit, and location near major centers with international airline connections. These factors could, however, be irrelevant to national firms operating in those countries, and even $13 \%$ of tens of millions of graduates creates a huge pool of talent for jobs at the multinationals. ${ }^{8}$ As McKinsey did not ask the recruiters the proportion of graduates from Western colleges and universities that met the standards of the multinationals, moreover, it is difficult to assess relative quality from these data.

\footnotetext{
${ }^{5}$ National Science Board (2012), table 2-35

${ }^{6}$ http://www.shanghairanking.com/ARWU2012.html\#

${ }^{7}$ http://www.timeshighereducation.co.uk/world-university-rankings/2013/reputation-ranking

8 Diana Farrell, Offshoring: understanding the emerging global labor market, Harvard Business School Press, 2006 p 14-15
} 
In any case, the educational standards of universities in lower income countries will surely rise over time as newly developed or expanded institutions upgrade their faculties and improve their academic practices. In addition, students throughout the world will benefit from the newest technology in higher education - the Massive Open Online Courses (MOOCs) that major US universities have developed and make available free over the Internet. ${ }^{9}$ Anyone in the world with Internet access can now take courses given by leading professors at major universities for free and obtain a certificate for completing the course and passing an exam. The two big university level MOOCs are consortia: Coursera (https://www.coursera.org/), which describes itself as a social entrepreneurship company that partners with the top universities in the world to offer courses online for anyone to take, for free; and EdX, an on-line consortium which includes Harvard and MIT, among other universities. EdX had about one million students in its first year of operation, with over two-thirds outside the US. Indicative of the reach and impact on the globalization of education, in spring 2013 Amol Bhave, a 17-year-old from Jabalpur, India, who took MIT's EdX circuits and electronics course over the Internet, was accepted at MIT for regular study on the basis of his performance. The goal of EdX is to educate one billion people around the world in the next ten years. ${ }^{10}$

Finally, while relatively few students obtain higher education outside of their own country, the number of international students is the fastest growing part of the global higher educational system. Exhibit 2 shows a near seven-fold increase in the number of international students between 1975 and 2010, producing a growth rate about three times as fast as that for all tertiary education students. In the US, the two top supplying countries for international students were China and India. International students are particularly important among the PhDs whose research underpins the scientific and technological base for modern industry and are a major source of supply for immigrant scientists and engineers.

\footnotetext{
${ }^{9}$ See http://www.moocs.co/Higher_Education_MOOCs.html for a listing of the massive open on-line courses in higher education.

10 Andrew Edgecliffe-Johnson "Online courses open doors for teenagers," Financial Times, March 26,2013 http://www.ft.com/intl/cms/s/0/c5a4b932-924c-11e2-851f-00144feabdc0.html\#axzz2UdebusFD
} 
Measuring the globalization of R\&D investments is a trickier business because the cost of research varies greatly among countries depending on the wages of researchers and other expenses. A country in which researchers are paid $1 / 2$ as much as in another country could spend half as much for the same real activity. In the absence of R\&D specific exchange rates, the US's National Science Foundation (NSF) uses purchasing power parities to compare expenditures across countries in comparable units. ${ }^{11}$ Such data show that until the 1990s advanced countries performed the vast bulk of R\&D but that in the 1990s and 2000s, China and some other developing countries had made huge inroads into global R\&D activity. In 2009 the United States accounted for $31 \%$ of global R\&D, down from $38 \%$ in 1999 and down from $40 \%-45 \%$ of global R\&D in the early 1970 s. China was the second biggest performer of R\&D, accounting for $12 \%$ of global $R \& D^{12}$ while Japan accounted for $11 \%$. The largest EU performer Germany spent $6 \%$ of global R\&D but the EU in its entirety accounted for $23 \%$. With several Asian countries beside China and Japan increasing R\&D expenditures substantially and with Brazil increasing its R\&D, the concentration of R\&D in the US and a few other advanced countries declined noticeably. Battelle predicts that China will outspend the US in R\&D by $2023 .{ }^{13}$ Another way to contrast $R \& D$ around the world is to compare $R \& D$ to GDP. The ratio of $R \& D$ to GDP are high for some smaller countries such as Sweden, Finland, Switzerland in Europe, Israel in the Mideast and Japan, South Korea, and Taiwan in Asia. ${ }^{14}$

The proof in the pudding for academic research and basic $R \& D$ is in the scientific papers that the research produces. Exhibit 3 shows that the number of scientific papers in the world doubled over the near thirty years covered in the table. The globalization of research can be seen in the changing shares of papers for different countries or groups of countries. With an increased number of

\footnotetext{
${ }^{11}$ See NSF Purchasing Power Parities: Preferred Normalizer of International R\&D Data http://www.nsf.gov/statistics/seind93/chap4/doc/4s293.htm

${ }^{12}$ The revision of China's PPP exchange rate in late 2007 lowered the dollar value of its R\&D expenditures, but this reduced the rate of increase of its share of world $R \& D$ rather than reducing it.

${ }^{13}$ Grueber, Martin and Tim Stud, The Internationalization of R\&D, R\&D Magazine 12/17/2012 http://www.rdmag.com/articles/2012/12/internationalization-r-d report Battelle's prediction.

${ }^{14}$ All of the data except for the early 1970s estimate of the US share of global R\&D are from the NSF Science and Engineering Indicators, table 4-19. The 1970s estimate is from National Science Board (1993), which only reports data for the major OECD countries, US, Japan, Germany, UK, Italy, and Canada.
} 
universities with faculties engaged in scientific research, growth of $\mathrm{PhD}$ and other $\mathrm{S} \& \mathrm{E}$ researchers, and R\&D spending, the developing countries raised their share of papers from $17.6 \%$ in 1981 to $27.1 \%$ in 2009 , largely at the "expense" of the US share of papers, which fell from $35.9 \%$ to $26.5 \%$. Among the developing countries, the biggest increase was for China, which produced almost no papers in 1981 and $9.4 \%$ of all papers in 2009. The Nordic states share of papers far exceeds their share of the world population but fell modestly as scientific production shifted to Asian developing countries.

Science has increasingly become a team activity, in which specialists with different skills and knowledge work together, often with complicated equipment, to make discoveries, leading to substantial increases in the number of authors on scientific papers in virtually every field. ${ }^{15}$ Exhibit 4 shows the increasing trend in co-authorship and in international co-authorship in all articles in the world and in US academic articles. In the data for the world the proportion of co-authored papers with an international author increased from $22 \%$ in 1990 to $35 \%$ in $2010^{16}$. In the US essentially all of the increase in co-authorship took the form of increased international co-authorship. Much as multinational firms use a global chain of production which combines the activities of persons in many countries, scientists increasingly rely on the work of persons of other nationalities and in other locations to produce their papers. Attributing papers to particular countries, as national science agencies do, gives a misleading picture of the actual process of scientific activity. Finally, in 2010, the most important collaborative relation in scientific work was between China and the US. Thirty percent of Chinese collaborations occurred with Americans and 14\% of US collaborations occurred with the Chinese. $^{17}$

In short, the evidence for globalization of knowledge and its production is overwhelming. What are the implications for the well-being of workers and economies writ large around the world?

\footnotetext{
${ }^{15}$ Wuchty S, Jones BF, Uzzi B. The increasing dominance of teams in production of knowledge.Science. 2007 May 18;316(5827):1036-9. Epub 2007 Apr 12.

${ }^{16}$ Calculated by taking the proportion of international co-authored papers divided by the proportion of all coauthored papers, as shown in the Exhibit.

${ }^{17}$ US NSF, Science and Engineering Indicators, 2012, Appendix table 5-41
} 


\section{Impacts of Globalization of knowledge and knowledge production}

Globalization of knowledge has wide-ranging effects on production and labor worldwide. To the extent that knowledge is a key factor in production, the spread and creation of knowledge is critical to economic development, comparative advantage, the flow of labor and capital among countries, and the spread of labor standards and norms about worker rights. Operating with or through the other rings of globalization, the spread of modern technological knowledge has arguably contributed to increased inequality within countries as well as to the convergence of income per capita among countries.

Consider first the impact of the globalization of knowledge and of research and development on the competitiveness of workers in advanced and developing countries. Debates over trade treaties and intellectual property rights highlight the importance of higher level education and of the ability to create new technology in advanced countries as providing comparative advantage compared to developing countries and protecting workers from low wage competition.

In the 1990s debate over the North American Free Trade Agreement (NAFTA), NAFTA advocates told Americans that Mexico would get labor-intensive industries with "bad jobs" that did not require much education while the US would get high tech industries with good jobs for well educated workers. As long as US workers maintained their years of schooling edge over Mexicans the US workers had nothing to fear from lower wage labor in Mexico. This view of a permanent education edge as protecting US workers from competition has been undermined by the rapid growth of higher education in Mexico and developing countries worldwide and by the ability of firms to outsource the work of the highly educated along global value chains

In the 1990s-2000s debate over the Agreement on Trade Related Aspects of Intellectual Property Rights (TRIPS) ${ }^{18}$ advanced countries sought to protect the patents, copywrites, and discoveries of the firms that developed new products and processes. The "North-South" or life cycle product model of trade develops the consequences of such protections for labor (Krugman, 1979). This

\footnotetext{
${ }^{18}$ http://www.wto.org/english/tratop_e/trips_e/intel2_e.htm
} 
model attributes the higher earnings of workers in advanced countries relative to the earnings of otherwise similar workers in developing countries to the advanced country monopoly of R\&D-induced technological change and production of technologically advanced goods and services. Firms pay workers more in the advanced North because the latest technology makes workers more productive than workers using older technologies in developing countries. The advanced country/developing country wage differential depends on the rate of technological advance in the North relative to the rate of imitation of technology in the South. Jones and Ruffin(2007) analyze the effects of technology transfer, which is a form of imitation of technology, on advanced countries under more complex conditions.

Globalization of knowledge and knowledge creation obsolesces this model. To the extent that technological development depends on the absolute number of scientists and engineers or other highly educated workers rather than the ratio of such specialists to less skilled workers, highly populous developing countries with large numbers of $S \& E$ workers can compete with advanced countries in high tech sectors. If China has 100,000 engineers working on green technology and France has 10,000 engineers, China is more likely to advance that technology than France. When multinational giants such as IBM and Microsoft first expanded research activities in China or India, their decisions made headlines. By the early 2010s, the availability of highly qualified workers at low cost had made it commonplace to locate research facilities in developing countries. ${ }^{19}$ With global production chains dispersing production worldwide, some analysts argue that the location of manufacturing in developing countries will itself lead to greater R\&D in those countries, as firms find that R\&D is more efficient in close proximity with the manufacturing facility. ${ }^{20}$ This reverses the causality on which the NorthSouth model is built. Manufacturing attracts R\&D rather than R\&D attracting new manufacturing.

19 Between 1997 and 2008 the share of U.S.-owned affiliates R\&D performed in China, South Korea, Singapore, and India rose from a half percentage point or less to $4 \%$ for China, just under $3 \%$ for South Korea, and just under $2 \%$ each for Singapore and India. Over roughly the same period, majority-owned affiliates of foreign MNCs located in the United States total business R\&D has fluctuated narrowly between 13\% and 15\%. National Science Board (2012),

${ }^{20}$ Pisano, Gary and Willy Shih, 2012; Isabel Tecu, 2013 
The evidence that globalization of knowledge has outrun the North-South model can be found not only in the greater dispersion of R\&D facilities worldwide described earlier but also in increased production and exports of high-tech products in developing countries (subject to the caveat that global supply chains make it difficult to assign products to countries). Panel A of Exhibit 5 shows a sizable shift in value added in knowledge and technology intensive industries from the US, EU, and Japan to the rest of the world between 1990 and 2010. With its huge investments in higher education and R\&D, China made a particularly large gain in its share of value added in the knowledge and technology intensive sectors. Panel B of Exhibit 5 shows an even greater shift in exports in high-tech goods from the US, EU, and Japan to other countries. Again China increased its share the most. In 2008-2009 the Obama Administration viewed green technologies as a way to restore US manufacturing jobs but soon discovered that China had become the leading place of production in some areas of solar technology. ${ }^{21}$

\section{Immigration of highly skilled and less skilled workers}

Almost by definition developing countries have a surfeit of unskilled workers relative to other factors of production compared to advanced countries, and pay those workers less than they could earn if they worked in advanced countries. Accordingly, large numbers of less skilled workers migrate from Mexico, Central America, the Caribbean, and Latin America to the US, many without documentation. Similarly, advanced Europe is the destination of many less skilled workers from Eastern Europe, the Maghreb, and other parts of Africa. Such immigration helps balance factor proportions among countries, consistent with Hecksher-Ohlin patterns of trade.

The surprise in immigration is that many highly skilled workers also migrate to advanced countries, adding to the imbalance in factor proportions via "brain drain". Underlying this flow are large wage differences across countries of workers with the same skills (Freeman and Oostendorp, 2000) that presumably result from the superior infrastructure and productive knowledge in advanced

\footnotetext{
${ }^{21}$ Wikipedia, List of countries by photovoltaics production (http://en.wikipedia.org/wiki/List_of_countries_by_photovoltaics_production) shows China share of solar photovoltaics production from less than $1 \%$ in $2000-01$ to over $40 \%$ in 2010 , while the US share fell from nearly $20 \%$ to $4-5 \%$. The quality of Chinese solar panels has created some problems, however (Woody, Todd, 2013).
} 
countries. International students are a major source of this migration. Students build job market skills and connections in the country in which they study that makes immigration easier. Some countries, such as Canada and Australia, give visas on the basis of skills, with Australia advantaging persons who obtain Australian degrees. In the US, over half of foreign-born science and engineering workers with a bachelor's degree, and over 2/3rds of foreign-born master's and PhD scientists and engineers obtained their highest degree in the US (Freeman, 2010b, table 5). Migration of highly educated workers to advanced countries strengthens their comparative advantage in skill-intensive sectors and reduces the incentive of multinationals to invest in $\mathrm{R} \& \mathrm{D}$ or other skill-intensive activities in developing countries.

While outflows of educated workers can create substantial skill shortages for small Caribbean islands, Central American, or African countries, the movement of educated persons from highly populous developing economies to advanced countries is unlikely to have much adverse effects on the source country. The number of migrants is modest compared to the increased numbers graduating from universities in those countries. With six million new university graduates every year and 28,000 new S\&E PhDs in China and with many Chinese getting doctorates in other countries, the loss of tens of thousands of bachelor's graduates or of hundreds of PhDs migrating to advanced countries barely slows the rapid increase in the pool of highly educated workers.

The migration of skilled immigrants to advanced countries has, moreover, advantages to developing countries. Some immigrants return to their birth countries with greater skills and income. Some move regularly between their birth countries and country of immigration, creating "brain circuluation" rather than brain drain (Saxenian, 2005). Studies of the flow of knowledge, largely based on the location of persons who co-patent, suggest that immigrants work with persons in their birth country to produce and pass knowledge quickly through ethnic networks (Kerr, 2008; . Agrawal, Kapur, McHale and Oettl (2011),), which could compensate for the immigrant inventing products or processes overseas. Ethnic networks are also connected with trade flows ( Rauch and Trindade (2002);Epstein and Gang (2004); Felbermayr et al 2010) and with multinationals forming new 
affiliates in countries (Foley and Kerr, 2013), expanding manufacturing in those areas (Kerr, 2008) and in future foreign direct investment (Kugler and Rapaport, 2007). The co-movement in skilled labor, trade and capital create unexpected economic outcomes in part because extant models do not explicitly treat the information and knowledge flows that are part of those movements.

\section{The pressures of trade on wages and employment}

The great fear of globalization critics was that increased trade between advanced and developing countries would adversely affect low skill workers in advanced countries and pressure developing countries to lower labor standards as they competed to attract foreign investments.

Since unskilled labor is the relatively scarce factor in advanced countries, that trade would reduce unskilled wages relative to skilled worker wages fits with standard trade theory and pressures toward factor price equilibrium with trading partners. During the NAFTA debate, however, treaty advocates denied that trade would harm workers and dismissed factor price equilibrium as theoretically "far more frail than currently imagined" (Bhagwati and Dehejia, 1993, p 8) and rejected factor content evidence that trade reduces the wages of unskilled workers by increasing their implicit supply. ${ }^{22}$ As trade with developing countries has grown, particularly with China, this position has become untenable. Comparing local labor markets more or less affected by Chinese imports to the US, Autor, Dorn and Hanson (2012) find that greater import pressures increase unemployment, lower labor force participation, and reduce wages with parameters that "explains one-quarter of the contemporaneous aggregate decline in U.S. manufacturing employment”. Diverse studies of the effect of offshoring find both wage and employment effects on workers, usually with evidence from the US. ${ }^{23}$ The result is not NAFTA opponent Ross Perot's "giant sucking sound"of jobs leaving advanced countries from trade, ${ }^{24}$ but pressures toward factor price equalization that show up in job displacement (which translates into

\footnotetext{
${ }^{22}$ Similarly, proponents of free trade rejected as unrealistic Samuelson's (2004) argument that developing country innovation in the products in which an advanced country specializes could shift comparative advantage to harm the advanced economy and ignored Gomory and Baumol's (2000) simulations of situations in which one country's gain in trade came at the expense of the other. There is no compelling evidence on the possible magnitude of these effects.

23 Robert C. Feenstra, 2011 summarize findings from over a dozen studies in his section on offshoring, wages and employment.

${ }^{24}$ http://en.wikipedia.org/wiki/Giant_sucking_sound
} 
lower wages on new jobs for the affected workers) as well as reductions in relative wages of workers in trade-impacted areas.

In the 1990s-2000s the challenge to the factor proportions analysis of the effect of globalization on labor markets has come from an different quarter: “The 1990's dealt a blow to traditional Heckscher-Ohlin analysis of the relationship between trade and income inequality, as it became clear that rising inequality in low- income countries and other features of the data wereinconsistent with that model. As a result, economists moved away from trade as a plausible explanation for rising income inequality... a number of new mechanisms have been explored through which trade can affect (and usually increase) income inequality ...within-industry effects due to heterogeneous firms; effects of offshoring of tasks; effects on incomplete contracting; and effects of labor-market frictions." (Harrison, et al 2010, p 1). As an example of the more subtle analysis necessary to explain patterns in the data Amiti and Davis (2009) differentiate between falls in tariffs on outputs and falls in tariffs on inputs on the wages of workers in firms in different positions in the the chain of production.

The increase in skill differentials in developing countries with abundant unskilled labor ${ }^{25}$ is mindful of the Leontief Paradox: the finding that in the aftermath of World War II (and later) the capital rich US exported labor-intensive products while importing products that were capital-intensive. Part of the explanation seems to lie in the greater education or human capital that American workers had over workers in other countries in the period (Keesing 1966; Kenan, 1966) and part also to differences in knowledge, with US exports concentrated in R\&D and knowledge-intensive activities and imports coming from sectors with less knowledge-based activity (Keesing, 1967).

Could the globalization of knowledge and knowledge creation have contributed to the increased inequality in developing economies in the 1990s? Since increased supply of graduates in developing

\footnotetext{
${ }^{25}$ The increase in inequality is not found in all developing countries nor consistently over time in the same country. For instance, Brazil and several other Latin American countries saw income inequality decline in the 2000s, due apparently to redistributive policies. But skill premiums increased in Argentina, Brazil, Colombia, India, and Mexico in the 1980s and 1990s as trade increased (Pavcnik, 2011, p 238)
} 
countries operates to reduce labor market inequality, any knowledge-based explanation must rest on the impact of the supply of graduates and R\&D on modes of production that benefitted skilled labor versus unskilled labor. That rapid increases in GDP per capita in developing countries did not expand employment in manufacturing and other formal sectors enough to reduce the share of workers working informally in developing countries suggests that transfer of technology and knowledge may have played a role. Cross section data show a strong inverse relation between the informal sector share of a work force and GDP per capita that implies that in the past, economic development reduced employment rapidly in the informal sector. . But in the 1990s-2000s the share of the work force in developing countries barely changed, making the informal normal. (Jütting and Laiglesia, 2009). The growth of global value chains - the fragmentation of production of goods and services into parts and tasks that could be offshored to many different countries - may also have changed the nature of globalization (OECD, 2013) in ways that benefitted skilled workers in developing countries relatively to unskilled workers in the informal sector.

Without gainsaying the 1990s increase in income inequality in some developing countries with globalization, evidence that income inequality fell in the 2000s in some of the same countries, including 12 of 17 Latin American (Gasparini and Lustig, 2011) also leaves open the possibility that the puzzle could be more about a temporary decadal phenomenon than about a longterm relation.

\section{effects on labor standards}

The greatest fear of critics of globalization was that globalization would set off a race to the bottom in labor standards as developing countries competed to attract foreign investment and boost exports. Egregious cases of low standards among subcontractors to multinational firms such as the worker suicides at Foxconn (subcontractor to Apple) and the 2013 collapse of the eight-storey Rana Plaza factory building in Bangladesh that killed over one thousand employees of subcontractors for 
major garment firms ${ }^{26}$ notwithstanding, however, globalization tended to improve rather than reduce labor standards around the world.

Why? One important factor was the spread of information about labor conditions that galvanized consumer pressures against bad working conditions. "Human rights vigilantes" - activists devoted to improving labor conditions in developing countries - succeeded in getting some brand name firms to monitor suppliers, to improve conditions, to identify suppliers so that the activists could independently monitor how their suppliers treated workers, and to develop codes of conduct for themselves and their subcontractors (Elliot and Freeman, 2005). Developing countries enacted protective labor legislation and signed the ILO's conventions on labor standards (Elliot and Freeman, 2003). In 2007 China enacted a new Contract Labor Law, which pressured firms to give written contracts to migrant and other workers and to pay legally required social insurance. Brazil increased its resources for implementing labor law. Pressed by unions and activists, the US, Canada, and some other advanced countries put labor standards clauses into trade clauses.

Examining the efforts of human rights and anti-sweatshop activists to improve working conditions and raise wages for workers in Indonesia, Harrison and Scorese concluded that "firms touched by the global market place were more, not less, likely to comply with labor standards (due in part) to ... pressure imposed by the United States, which used the GSP as a mechanism to enforce labor standards in Indonesia, combined with increasing human rights activism"(Harrison and Scorse, 2003, p 80). But they also note that while "activism significantly improved wages for unskilled workers in sweatshop industries, (it) probably encouraged some plants to leave Indonesia." (Harrison and Scorse, 2004, introduction). The job of the activists is to balance improvements in wages and labor conditions against the risk of job loss or plant closure from their campaigns Overall, the activists appear to have succeeded in doing this. In their review of job accident rates, child labor, and violations of civil rights in Asia, and the linkage between foreign direct investment and labor regulations among

${ }^{26}$ http://www.bbc.co.uk/news/world-asia-22476774 
all countries, Flanagan and Khor (2012, p 280) concluded that "a broad improvement in working conditions and labour rights around the world accompanied a significant expansion of international trade and investment." 27

\section{Conclusion}

The globalization of economic activity that has spread the benefits of modern technology around the world and helped improve living standards in traditionally low income countries produced some unexpected changes in the labor market and economy writ large. Globalization was accompanied by a huge spread of knowledge and knowledge creation that influenced factor flows, productivity, and comparative advantage. It created some difficult adjustments for workers in both developing countries and advanced countries and produced worldwide pressures for better labor standards rather than creating a race to the bottom in standards. While globalization of knowledge and knowledge creation may not be the key factor underlying the effects of globalization on labor, per my one ring analogy, the evidence in this paper has hopefully convinced the reader that the spread of knowledge is on par with the more widely studied trade, international capital flows, and immigration in determining outcomes and can help explain some otherwise puzzling patterns in the effects of globalization on labor.

\footnotetext{
${ }^{27}$ They stress the importance of growth of GDP in improving standards rather than the role of activists in effectuating change and note that immigration also places pressures on countries to improve standards as workers will migrate from countries with low standards to those with higher standards.
} 


\section{REFERENCES:}

Agrawal, Ajay, Devesh Kapur, John McHale, and Alexander Oettl. 2011. "Brain Drain or Brain Bank? The Impact of Skilled Emigration on Poor-Country Innovation", Journal of Urban Economics, 69: 4355.

Amiti, Mary, and Donald Davis. 2009. “Trade, Firms, and Wages: Theory and Evidence.” NBER Working Paper No. 14106

Autor David. David Dorn, and Gordon H. Hanson. "The China Syndrome: local labor market effects of import competition in the United States" http://www.nber.org/papers/w18054.pdf

Bhagwati Jagdish. 1998. "The Capital Myth: The Difference between Trade in Widgets and Dollars," Foreign Affairs, May/June.

Bhagwati, Jagdish Bhagwati and Vivek Dehejia. 1993. "Freer Trade and Wages of the Unskilled: Is Marx Striking Again?” Discussion Paper No. 672 The Influence of International Trade on U.S. Wages American Enterprise Institute, September 10.

Edgecliffe-Johnson, Andrew. 2013. “Online courses open doors for teenagers," Financial Times, March 26. http://www.ft.com/int1/cms/s/0/c5a4b932-924c-11e2-851f-

00144feabdc0.html\#axzz2UdebusFD

Elliott, Kimberly Ann and Richard B. Freeman. 2003. Can Labor Standards Improve Under Globalization? Washington, DC: IIE.

Elliott, Kimberly Ann and Richard B. Freeman. 2004. "White Hats or Don Quixotes? Human Rights Vigilantes in the Global Economy, in Emerging Labor Market Institutions for the Twenty-First Century (editors, Richard Freeman, Joni Hersh, Larry Mishel), University of Chicago Press for NBER.

Epstein, Gil S., Ira N. Gang. 2004. "Ethnic Networks and International Trade,” IZA Discussion paper series, No. 1232

Farrell, Diana. 2006. Offshoring: understanding the emerging global labor market, Harvard Business School Press, p 14-15.

Feenstra, Robert C. 2011. "The International Trade and Investment Program” NBER Reporter. Number 2 issue of the http://www.nber.org/programs/iti/

Felbermayr, Gabriel, Benjamin Jung and Farid Toubal. 2010. "Ethnic Networks, Information, and International Trade: Revisiting the Evidence," Annales d'Economie et de Statistique, ENSAE, issue 9798, pages 41-70.

Flanagan, Robert and Nina Khor. 2012. "Trade and the quality of employment: Asian and non-Asian economies," in OECD, Policy Priorities for International Trade and Jobs, (ed.), D. Lippoldt, epublication, available at: www.oecd.org/trade/icite.

Foley, C. Fritz, and William R. Kerr. "Ethic Innovation and U.S. Multinational Firm Activity." (forthcoming, 2013). 
Freeman, Richard B. 2010a. "What Does Global Expansion of Higher Education Mean for the US?" in Charles Clotfelter (ed) American Universities in a Global Market, University of Chicago for NBER.

Freeman, Richard B. 2010b. "Globalization of scientific and engineering talent: international mobility of students, workers, and ideas and the world economy," Economics of Innovation and New Technology, 19: 5, 393-406.

Freeman, Richard B. and Remco Oostendorp. 2000. "Wages Around the World: Pay Across Occupations and Countries," NBER Working Papers 8058, National Bureau of Economic Research, Inc.

Gasparini, L. and N. Lustig. 2011. "The Rise and Fall of Income Inequality in Latin America," Working Papers, No. 1110, Tulane University, Department of Economics.

Gomory, Ralph E. and William J. Baumol. 2000. Global Trade and Conflicting National Interests, MIT Press.

Grueber, Martin and Tim Stud. 2012. "The Internationalization of R\&D,” R\&D Magazine, December 17.

Harrison, Ann, John McLaren, and Margaret S. McMillan. 2010. "Recent Findings on Trade and Inequality," NBER WP 16425, September.

Harrison, Ann and Jason Scorse. 2003. "Globalization's Impact on Compliance with Labor Standards," Brookings Trade Forum, pp. 45-96.

Harrison, Ann and Jason Scorse. 2004. "Moving Up or Moving Out? Anti-sweatshop activists and labor market outcomes," NBER Working Paper 10492.

Harrison, Ann, John McLaren, and Margaret S. McMillan. 2010. "Recent Findings on Trade and Inequality,” NBER Working Paper No. 16425.

Jones, Ronald W. and Roy J. Ruffin. 2007. "International Technology Transfer: Who Gains and Who Loses?" Review of International Economics 15(2): 209-222.

Jütting, Johannes and Juan R. de Laiglesia. 2009. "Is Informal Normal?: Towards More and Better Jobs in Developing Countries." OECD Paris.

Keesing, Donald. 1966. "Labour Skills and Comparative Advantage” American Economic Review vol 56 May 1966.

Keesing, Donald B. 1967. "The Impact of Research and Development on United States Trade," Journal of Political Economy Vol. 75, No. 1 (Feb., 1967), pp. 38-48.

Keneen, P. B. 1966. "Nature, Capital, Trade” Journal of political Economy vol 73, October.

Kerr, William. 2008. "Ethnic Scientific Communities and International Technology Diffusion", Review of Economics and Statistics 90:3, 518-537. 
Krugman, Paul. 1979. “A Model of Innovation, Technology Transfer, and the World” Journal of Political Economy, Vol. 87, No. 2, April.

Kugler, Maurice, and Hillel Rapoport. 2007. "International Labor and Capital Flows: Complements or Substitutes?" Economics Letters 92:2, 155-162.

Markusen James R. 1983. "Factor movements and commodity trade as complements," Journal of International Economics Volume 14, Issues 3-4 (May): Pages 341-356.

National Science Board. 1993. Science and Engineering Indicators 2012. Arlington VA: National Science Foundation (NSB 93-01).

National Science Board. 2006. Science and Engineering Indicators 2012. Arlington VA: National Science Foundation (NSB 06-01).

National Science Board. 2012. Science and Engineering Indicators 2012. Arlington VA: National Science Foundation (NSB 12-01).

OECD. 2013. Interconnected Economies: Benefitting from Global Value Chains.

Pavcnik, Nina. 2011. "Globalization and within country income inequality" in Making Globalization Socially Sustainable, www.wto.org/english/res_e/booksp_e/glob_soc_sus_e_chap7_e.pdf

Pisano, Gary and Willy Shih. 2012. "Does America Really Need Manufacturing?" Harvard Business Review http://hbr.org/2012/03/does-america-really-need-manufacturing/ar/1;

James E. Rauch and Vitor Trindade. 2002. "Ethnic Chinese Networks in International Trade" The Review of Economics and Statistics, Vol. 84, No. 1 (February), pp. 116-130.

Samuelson, Paul A. 2004. "Where Ricardo and Mill Rebut and Confirm Arguments of Mainstream Economists Supporting Globalization”, Journal of Economic Perspectives, 18(3): 135-146

Saxenian, Annalee . 2005. "From Brain Drain to Brain Circulation: Transnational Communities and Regional Upgrading in India and China," Studies in Comparative International Development V 40, N 2, Summer.

Tecu, Isabel. 2013. “The location of industrial innovation: does manufacturing matter?” CES 13-09 March.

Wong, Kar-yiu. 1986. “Are international trade and factor mobility substitutes?” Journal of International Ecnomics Volume 21, Issues 1-2 (August) Pages 25-43

Woody, Todd. 2013. "Solar Industry Anxious Over Defective Panels," New York Times (May 28), available at: http://www.nytimes.com/2013/05/29/business/energy-environment/solar-powers-darkside.html?pagewanted=all Print Edition titled as "Solar Power's Dark Side," New York Times (May 29) Pg B-1.

Wuchty S, Jones BF, Uzzi B. 2007. "The increasing dominance of teams in production of knowledge," Science May 18;316 (5827):1036-9. Epub 2007 Apr 12. 
Exhibit 1: Millions of Enrollments and Shares of enrollment (in parentheses) in Tertiary

Education, by Area of the World, 1970-2010

\begin{tabular}{|c|c|c|c|c|}
\hline Area & 1970 & 1980 & 1990 & 2010 \\
\hline World & 29.4 & 55.3 & 67.6 & 177.6 \\
\hline \multirow[t]{2}{*}{ Developing } & 16.0 & $35.0(63 \%)$ & 41.0 & $136.5(76 \%)$ \\
\hline & $(54 \%)$ & & $(61 \%)$ & \\
\hline China & $<0.1$ & 1.7 & 3.8 & 30 \\
\hline India & 2.5 & 3.5 & 5 & 20.7 \\
\hline \multirow[t]{2}{*}{ US } & 8.5 & $12.1(22 \%)$ & 13.7 & $20.4(11 \%)$ \\
\hline & $(29 \%)$ & & $(20 \%)$ & \\
\hline \multirow[t]{2}{*}{ Other adv } & 4.9 & $8.2(15 \%)$ & 12.9 & $23.7(13 \%)$ \\
\hline & $(17 \%)$ & & $(19 \%)$ & \\
\hline
\end{tabular}

Source: UNESCO, Institute for Statistics, on line files, 2010 from tables 15, 20A 


\section{Exhibit 2: International Students Fastest Growing Part of Higher Education}

$\begin{array}{lc}\text { year } & \text { Int'l Students, World } \\ 1975 & 600,000 \\ 1980 & 800,000 \\ 1990 & 1,200,000 \\ 2000 & 1,900,000 \\ 2010 & 4,100,000\end{array}$

Source: OECD, Education at a Glance, 2012 p 24 and IIE, International Students and Mobility http://exchanges.state.gov/universitysummit/mobility_report.pdf 
Exhibit 3: Numbers of Scientific Papers in World and Percentage of papers by country, 1981-2009

\begin{tabular}{|l|c|c|}
\hline Area & 1981 & 2009 \\
\hline World & $369,000(100$ & $788,347(100 \%)$ \\
\hline Developing & 17.6 & 27.1 \\
\hline China & 0.3 & 9.4 \\
\hline India & 3.2 & 2.5 \\
\hline South Korea & 0.2 & 2.8 \\
\hline US & 35.9 & 26.5 \\
\hline Other advanced & 46.5 & 46.4 \\
\hline Nordic Countries & 3.6 & 3.1 \\
\hline
\end{tabular}

Source: 2009, National Science Board (2012), table 5-27, available at http://www.nsf.gov/statistics/seind06/tables.htm. 1981, National Science Board (2006), table 5-32, available at http://www.nsf.gov/statistics/seind96/chap_5.pdf 
Exhibit 4: The Move to International Coauthorships Exhibit 4: The Move to International Coauthorships

\section{World and U.S. academic S\&E articles coauthored domestically and internationally: 1990-2010}
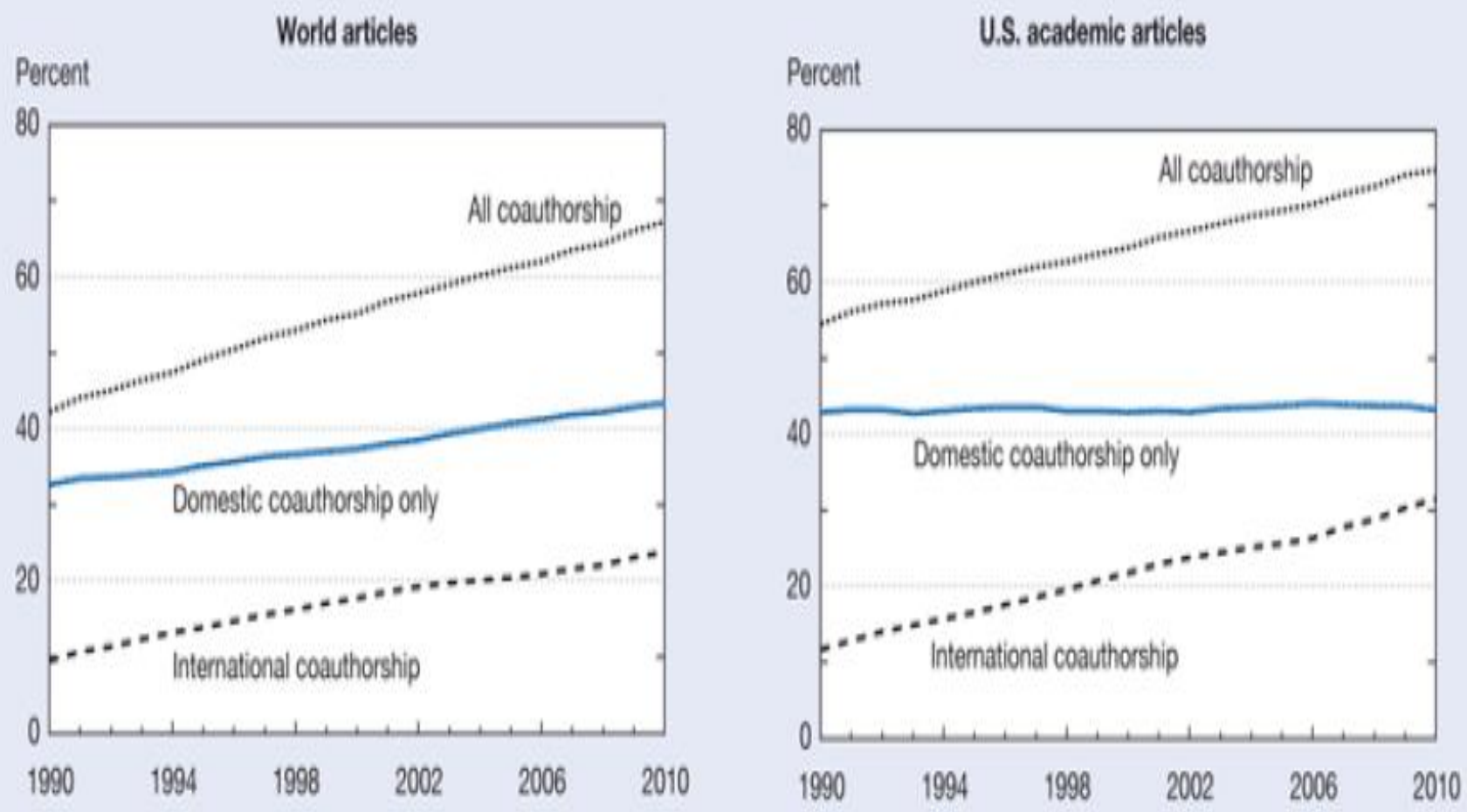

NOTES: Article counts from set of joumals covered by Science Citation Index (SC) and Social Sciences Citation Index (SSC), Aticles classified by year they entered database, rather than year of pubication, and assigned to country/economy on basis of institutional address(es) listed on article. Articles on whole-count basis, i.e, each collaborating institution or country credited one count. Intemationally coauthored articles may also have multiple domestic coathors.

SOURCES: National Science Foundation, National Center for Science and Engineering Statistics, and The Patent Board"', special tabulations (2011) from Thomson Reuters, SCl and SSCl, hitp//thomsonreuters.com/products_services/sciencel.

Data for this exhibit are below: 
World and U.S. academic S\&E articles coauthored domestically and internationally: 19902010

(Percent)

\begin{tabular}{|c|c|c|c|c|c|c|}
\hline \multirow[b]{2}{*}{ Year } & \multicolumn{3}{|c|}{ World articles } & \multicolumn{3}{|c|}{ U.S. academic articles } \\
\hline & $\begin{array}{l}\text { Domestic } \\
\text { coauthorship } \\
\text { only }\end{array}$ & $\begin{array}{l}\text { Interna } \\
\text { coauth }\end{array}$ & $\begin{array}{l}\text { I All } \\
\text { pcoauthorship }\end{array}$ & $\begin{array}{l}\text { Domestic } \\
\text { coauthorship } \\
\text { only }\end{array}$ & $\begin{array}{l}\text { Intern } \\
\text { coautl }\end{array}$ & $\begin{array}{l}\text { I All } \\
\text { pcoauthorship }\end{array}$ \\
\hline 1990 & 32.72 & 9.52 & 42.24 & 42.84 & 11.71 & 54.56 \\
\hline 1991 & 33.42 & 10.64 & 44.06 & 43.24 & 12.91 & 56.15 \\
\hline 1992 & 33.71 & 11.43 & 45.14 & 43.18 & 14.01 & 57.20 \\
\hline 1993 & 33.99 & 12.37 & 46.35 & 42.80 & 14.85 & 57.66 \\
\hline 1994 & 34.38 & 13.12 & 47.50 & 43.05 & 15.77 & 58.82 \\
\hline 1995 & 35.19 & 13.93 & 49.12 & 43.40 & 16.61 & 60.01 \\
\hline 1996 & 35.73 & 14.67 & 50.41 & 43.49 & 17.55 & 61.04 \\
\hline 1997 & 36.28 & 15.62 & 51.90 & 43.52 & 18.49 & 62.01 \\
\hline 1998 & 36.63 & 16.26 & 52.90 & 43.12 & 19.62 & 62.74 \\
\hline 1999 & 37.10 & 17.14 & 54.23 & 43.02 & 20.74 & 63.77 \\
\hline 2000 & 37.42 & 17.69 & 55.11 & 42.91 & 21.68 & 64.59 \\
\hline 2001 & 38.11 & 18.64 & 56.76 & 43.01 & 22.90 & 65.91 \\
\hline 2002 & 38.59 & 19.24 & 57.83 & 42.94 & 23.74 & 66.68 \\
\hline 2003 & 39.32 & 19.75 & 59.07 & 43.39 & 24.41 & 67.80 \\
\hline 2004 & 40.08 & 20.09 & 60.17 & 43.61 & 25.10 & 68.71 \\
\hline 2005 & 40.75 & 20.43 & 61.17 & 43.72 & 25.61 & 69.33 \\
\hline 2006 & 41.24 & 20.87 & 62.11 & 44.07 & 26.25 & 70.32 \\
\hline 2007 & 41.89 & 21.62 & 63.51 & 43.87 & 27.77 & 71.64 \\
\hline 2008 & 42.24 & 22.15 & 64.39 & 43.80 & 28.84 & 72.63 \\
\hline 2009 & 42.96 & 23.10 & 66.07 & 43.66 & 30.39 & 74.05 \\
\hline 2010 & 43.42 & 23.83 & 67.25 & 43.28 & 31.57 & 74.85 \\
\hline
\end{tabular}


Exhibit 5: Distribution of Knowledge and Technology-Intensive Industries and of Exports of High-Technology Goods by country, 1990-2010

Panel A: Percentage of Global Value Added in Knowledge and Technology-Intensive Industries

\begin{tabular}{|l|c|c|}
\hline & 1990 & 2010 \\
\hline US & 35.1 & 32.5 \\
\hline EU & 33.8 & 27.8 \\
\hline JAPAN & 13.4 & 8.9 \\
\hline Total & 82.3 & 69.2 \\
\hline China & 1.5 & 6.8 \\
\hline Asia-8 & 3.4 & 5.9 \\
\hline All other countries & 11.8 & 18.1 \\
\hline
\end{tabular}

Panel B: Percentage of Global Exports of High-Technology Goods

\begin{tabular}{|l|c|c|}
\hline & 1995 & 2010 \\
\hline US & 15 & 11.6 \\
\hline EU & 31.9 & 28.9 \\
\hline JAPAN & 15.1 & 5 \\
\hline Total & & 62 \\
\hline China & 7.6 & 23.7 \\
\hline Asia-8 & 21.6 & 20.6 \\
\hline All other countries & 9.8 & 10.2 \\
\hline
\end{tabular}

Source: National Science Board (2012), Appendix table 6.1 and 6.24 